\title{
ASCETICISM AS A FACTOR OF SELF-IMPROVEMENT IN THE CHRISTIAN TRADITION OF THE UKRAINIAN MIDDLE AGES
}

\section{Hudzenko O.}

\section{INTRODUCTION}

Today, in the conditions of transformation of civilizational values, special attention is paid to the revival of universal and national ideals, which invariably border on the eternal aspirations of man to spiritual self-development and self-improvement. In a situation of spiritual crisis, asceticism is increasingly attracting the attention of researchers as a practice of moral improvement, self-realization, and the disclosure of the individual's intellectual potential.

In particular, V. Zhadan considers hedonism and asceticism in the dynamics of culture (Zhadan, 2006), L. Sidak establishes the specifics of asceticism as a principle of self-development and self-realization of the individual (Sidak, Asceticism, 2003), G. Goncharov reveals the social origins of ascetic ideal and ascetic practice. (Goncharov, 2012), O. Danyliuk considers the philosophical and theological problem of silence in the ascetic tradition of Latin monasticism (Danyliuk, 2013). The influence of Orthodox asceticism on the sociocultural existence of the Ukrainian people in the historical and philosophical context was considered by V. Petrov, V. Gorsky, I. Ogorodnik, M. Rusyn, S. Bondar, V. Nichyk, J. Stratiy, and others. In our opinion, in the perspective of the mentioned issues, it is especially important to address the historical and philosophical heritage within the Ukrainian national tradition to critically comprehend the ascetic historical and philosophical heritage of our people and its further use in today's conditions.

The purpose of the research, from which its tasks follow, is to identify the peculiarities of asceticism of the Ukrainian Middle Ages and Renaissance humanism in the context of the world ascetic tradition.

The scientific novelty lies in the focus of our research on the analysis of the peculiarities of the representation of ascetic traditions in the spiritual culture of Ancient Rus, Renaissance humanism and early Baroque in Ukraine. We turned to textual, comparative-historical and systematization methods in connection with the analysis of texts and were guided by the principles of objectivity and historicism. This 
study is based on a religious approach to the study of historical and philosophical problems.

\section{Asceticism in the spiritual culture of society}

Turning to the historical and philosophical heritage and scientific achievements of our contemporaries, we will try to consider asceticism as a means of self-development in the Ukrainian Middle Ages.

In particular, V. Zhadan notes that the concept of "asceticism" is derived from the ancient Greek word $\alpha \sigma \kappa \eta \sigma \iota \varsigma$ ("exercise"). Accordingly, the words formed from it denote the teachings and their followers, who focus on self-improvement through various spiritual and physical exercises. In Christian culture, the concept of asceticism was fixed mainly on religious interpretation. Asceticism was considered a necessary condition for the mystical ascent to the contemplation of God. What is decisive is that it requires external and internal struggle with the sensory-material world (Zhadan, 2006).

It is noteworthy that Christian asceticism is characterized not only by the struggle with passions, but also by the ability to endure them as suffering as an imitation of the "passions of Christ"; physical (killing the flesh) and spiritual (humility, chastity, obedience, silence) restraint; sacrifice and mercy; observance of the sacraments of confession and repentance; focus on feat and achievement of grace; keeping the commandments of service to God and man (Zhadan, 2005: 58).

According to L. Sidak, asceticism is an integral part of the spiritual culture of society, which protects it from the negative phenomena caused by the selfish determination of the subconscious activities of its members (Sidak, Nature, 2003: 156). Considering asceticism as a principle of personal self-development, the researcher defines self-realization as one of the most important existential needs of man, which is met primarily in the form of self-improvement, ie self-centered creative volitional activity, consciously and subconsciously aimed at human renewal, denial of the existing imperfect state and approach to the conscious ideal, as well as the implementation of goals in activities for themselves and society. Asceticism, according to the author, is a mechanism that ensures the successful nature of such activities (Sidak, Asceticism, 2003: 13).

Thus, as O. Rozumna rightly points out, the essence of a true ascetic ideal lies in the eternal desire of man to improve both his natures (corporeal and spiritual) and, accordingly, in the perception of man as a spiritual-corporeal whole (Rozumna, 2004: 3). 
The doctrine of the ascetic ideal is the anthropological concept of Orthodox theology, which defines man as a spiritual and material whole. It is combined with the recognition of the insubstantiality of evil and with the doctrine of the apophatic path of knowledge of the transcendent, which directs man to self-knowledge. This doctrine is implemented through some ascetic practices that involve the gradual ascent of the hierarchy, the "ladder" of virtues. The lowest virtues are available to a wide range of parishioners - work, fasting, prayer. The following stages are subordinated only to the chosen - Christian ascetics. Most often, an ascetic feat requires solitude to achieve states of gnosis, which precedes deification as the ultimate goal of the Christian life (Rozumna, 2004: 9).

O. Rozumna identifies the following structural components of the ascetic ideal: doctrinal-dogmatic (ideal man as spiritual and corporeal integrity, violated by the Fall); praxeological (restoration of spiritual and bodily integrity of man through deification through a number of practices); preaching (the need to spread the doctrine to implement it in concrete life) (Rozumna, 2004: 8).

The scholar notes that in Christianity ascetic doctrine develops simultaneously with the formation of the first theological concepts (Rozumna, 2004: 8). Accordingly, she identifies the following stages in the Orthodox preaching of the ascetic ideal: the concept of Clement of Alexandria; generalized by Maxim the Confessor ascetic doctrine of patristics (Vasil the Great, John Zlatoust, Gregory Bogoslov, Gregory of Nyssa); tradition of hesychasm (Gregory Palamas) (Rozumna, 2004: 10).

Hesychasm is a mystical and ascetic doctrine that underlies the Eastern Christian, Orthodox monastic spirituality. Among domestic monasticism, it became widespread after the fourteenth century. Through mystical contemplation, a higher level of knowledge can be achieved - contemplation of the essence of things, the vision of uncreated light, knowledge of God. Hesychasm denies the possibility of knowing God through the intellect (Humeniuk, 2013: 156). Hesychasm as a mystical-spiritual practice presupposes a two-level structure of the spiritual ascent of the individual to his integrity. Thus, asceticism is a prerequisite for a mystical act, a kind of active work of man on his inner essence (Mozhovyi, 2011: 46). The ideological forerunners of hesychasm are considered to be Macarius of Egypt and Ivan Listvychnyk, as well as Ivan Sirin. Prayer has a deep epistemological significance and in mystical contemplation reveals the 
transcendent meaning of "knowledge of the logos of things" (Humeniuk, 2013: 157).

Thus, as S. Humeniuk rightly points out, the mystical practice of hesychia is the core of traditional Orthodox culture and, in fact, becomes a guarantee of the preservation of the Eastern Christian patristic tradition (Humeniuk, 2013: 156-167). Hesychasm significantly influenced the further development of the ascetic worldview in Ukrainian philosophical thought (Mozhovyi, 2011: 47).

\section{Christian austerity in the Ukrainian tradition}

Among the historical stages of Ukrainian culture development, there are two most significant for the phenomenon of Christian asceticism in the Ukrainian tradition: the Kievan Rus' period (princely period, IX-XII centuries) and the Ukrainian Baroque era (XVI-XVIII centuries) (Piletsky, 2012: 24).

E. Piletsky notes that the evolution of asceticism from the moral to the mystical modus, inherent in Eastern Christian asceticism, is traced in the development of Ukrainian religious thought. Also, referring to the research of Archbishop I. Isichenko, the scholar notes that since the Christian culture of Kievan Rus was a peripheral part of Byzantine civilization, the Rus ascetic literature of the XI-XIII centuries. belonged to the general context of Eastern medieval writing (Piletsky, 2012: 24). Accordingly, the ascetic literature of this period is represented mainly by translated Byzantine prose.

Among the original ascetic works are "The Word of Law and Grace" by Metropolitan Hilarion of Kyiv (XI century), "The Life of Reverend Father Our Theodosius" by Nestor the Chronicler (middle of XI century), "Teachings to the Brotherhood" by Luka Zhydyata (XI century), works of Cyril of Turov and Kyryk of Novgorod (XII century), "Teachings" of George Zarubsky (XII-XIII centuries), social and ascetic works by Ep. Serapion Volodymyrsky, "KyivPechersk Paterik". Early medieval Rus ascetic literature is attributed to the "moral" direction of ascetic practice (Piletsky, 2012: 24).

The philosophy of the Baroque era synthetically combined the "ratio" of Western scholasticism and the new philosophy and Christian mysticism (Piletsky, 2012: 25). In the Ukrainian philosophical culture of this period, as well as in the views of thinkers of the Western European Middle Ages, ascetic ideas and values prevailed. 
It should be noted that at the early modern stage an important contribution to the revival of hesychasm, mystical and apophatic theology, the development of ideas of deification through selfknowledge was made by the Ostroh branch and the Academy and Orthodox fraternities and fraternal schools. Thus, the ascetic contemplative current, which was based on the philosophy of Byzantine hesychasm and preached the humanistic principles of early Christianity, was represented, in particular, by Gerasim Smotritsky, Ivan Vyshensky, Yov Knyagynytsky, Yov Pochaivsky, Isaiah Kopynsky, Vitaly from Dubno. It is noteworthy that in the Ukrainian asceticism, carried out on the model of hesychastic, there was a balanced position on the internal and external service to God and people (Shadyuk, 2015: 22).

\section{Asceticism in Kievan Rus}

Ancient Rus saints set a perfect spiritual existence as a common life goal. But, according to historical data, they went to it in different ways. In particular, G. Fedotov, exploring the peculiarities of ancient $\mathrm{n}$ holiness, identified two types of spirituality, which were founded by the founders of the Kyiv-Pechersk Lavra: Saints Anthony and Theodosius. Theodosius of Pechersk was the founder of the Palestinian tradition in Rus, the first Pechersk ascetic who consciously adapted the monastic orthodoxy of Mount Athos to the ancient Rus reality. The monk was canonized by the church earlier by his teacher Anthony. It was in the person of Theodosius that Kievan Rus found its ideal of a perfect, holy life. It was characterized by evangelical obedience and non-resistance. Anthony's way is cave, ascetic-heroic; Theodosius is aboveground, socially charitable: "Their roots go back to the two-sided tradition of the Greek East: Palestinian and EgyptianSyrian-Athos" (Fedotov, 1990: 77).

G. Fedotov believes that we have the right to talk about the humanization of the ascetic ideal in Palestine and also - in Rus because the ideal of holiness in Rus is closer to the Palestinian tradition. In particular, the Palestinians do not resort to extreme ascetic measures. Their austerity is abstinence: fasting, sleep deprivation, and physical labor. Theodosius formulated important political demands that defined the church line in the era of separate principalities and gave the appropriate ideal of the Christian righteous, which is the basis of religious propaganda. Theodosius urges the brothers to arm themselves with fasting and prayer, to know God through tears and 
obedience. He is known for his "Teachings of the Benefit of the Soul", in which he demands repentance and full awareness of deeds and thoughts from the brethren. In particular, the young years of Theodosius in Nestor's account should testify to the saint's innate desire for "poverty", the desire to repeat the earthly path of Christ, "full of social humiliation" (Gorsky, 1994: 132).

Anthony's school represents a tougher - Syrian - tradition in Rus. It is noteworthy that the "Kyiv-Pechersk Paterik" is dominated by the type of Anthony Pechersky (Fedotov, 2001: 6). From historical and chronicle evidence it is known that the saint was on Mount Athos, the type of his austerity borrowed from the elders of the Holy Mountain. Therefore, the monk adopted asceticism on the Syrian model, which is characterized by incessant repentance, bodily suffering. Anthony's school was the first successful attempt by Rus monks to imitate Eastern models.

Thus, in Rus in the process of Christianization there were two forms of monastic life, which represented different political and theological orientations. One of them was introduced by the reform of Prince Volodymyr Sviatoslavych and was developed on the traditional principles that defined the system of the Slavic-pagan religious organization. The second was born in the conditions of the disintegration of centralized power and with the blessing of the "Holy Mountain" resulted in Orthodox ascetic asceticism, which later spread throughout church practice.

All monasteries were founded in ancient Rus near the cities. After all, they, serving as a source of religious and spiritual mentoring of the laity, depended on their material support. From the very beginning, the Pechersk Monastery became an important book center of Kievan Rus. Much attention was paid to the translation and rewriting of books. The literary preferences of the Pechersk ascetics were largely determined by the disintegration of Christianity into Orthodoxy and Catholicism (1054). Therefore, the monks considered it their task to oppose any ties between Rus and the West, to protect and plant the mystical and ascetic theology of the Byzantine Church. In particular, the abbot of the Kyiv-Pechersk Monastery Theodosius in his work "A Word on the Christian and Latin Faith" opposed the Catholic Church, accusing it of deviating from the general Christian traditions (Adamchuk, 2003: 73).

Thus, the Christian ideal of man is a hermit monk, an ascetic who, having embarked on the path of spiritual formation, seeks contact of 
his soul with God through prayers and fasting. His life is built on the basis of strict moral precepts and ritual forms. Aiming to "follow" Christ, he seeks first of all miracles, making them the only way to comprehend the deity and become partakers of his gracious mystery. The antithesis of "world - monastery" in the medieval consciousness acquires universal significance, asserting a deep intransigence, the hostility of spirit and body, divine and natural. It should be noted that due to the fact that some virtues are mechanically attached to others without internal connection, there was a combination of secular and ecclesiastical ideals. In particular, in the works of secular literature to the virtues of the prince (he is depicted as a good warrior and a good leader of the army (not seductive at feasts, generous and brave)) joining the spiritual virtues of an ascetic nature: humility, piety, etc. It should be noted that the Christian worldview in the depiction of people was put in the service of strengthening the feudal system.

Christian spirituality in Rus, preserving the ascetic tradition of Byzantium, strengthened the evangelical element, which focuses on active love, service to people, charity. Thus, the ideal in Kievan Rus is moral existence; the process of self-improvement acquires the meaning of formation, development of the spirit. Personality focuses on him in the organization of their activities. He becomes the embodiment of absolute values, concentrated in a higher, divine space, correlated with the concepts of goodness and perfection. This high level of spirituality is the opposite of "low", immoral, space.

In Orthodox monasticism, salvation by works also prevails over salvation by faith. Ancient Rus' monasticism, in contrast to the Byzantine and Western European, was not a product of the crisis period. Thus, his ideal of ascetic life was not formed in times of spiritual crisis. The norms of Christian behavior, absolutized by the monastic consciousness, vividly illustrate paterics - hagiographic works that describe the lives of saints (Gorsky, 1994: 12-13).

Let us turn to the "Kyiv-Pechersk Paterik", an outstanding work of literature of Kievan Rus, which, as a whole work and a system of legendary short stories based on the legends of the XI-XII centuries, appeared in the early XIII century. From it, we learn that the place where the monastery stands was considered sacred. For the sake of bliss in the Kingdom of God, monks renounce earthly pleasures. They are always immersed in prayer and repentance, contemplation of their imperfections, strive for solitude, and promise complete silence: "...and everyone is in love, the lesser obeying the elders... in the same way the 
elders have a love for the lesser... Such is the divine love in that holy brotherhood, abstinence, and humility" (Abramovich, 1991: 94).

The fall is interpreted as the result of indulgence in the flesh, not as a consequence of a moral, spiritual defect. In the most carnal - not sinfulness, but only weakness. Sinfulness is a violation of the harmony of the two components of human nature. It could manifest itself not only in the absolute following of the bodily principle, but also in the excessive restriction of his rights. Sinlessness, as the true origin of human nature, presupposes in itself the act of creation of man by God, according to which ancient $\mathrm{n}$ thinkers interpreted it as a combination, an intertwining of material and spiritual.

\section{Ascetic tradition in Ukraine in the XVI-XVII centuries}

Ivan Vyshensky (1550-1621) was the most expressive representative of the mystical and ascetic direction of the Ukrainian religious and philosophical tradition of the early humanism period. Obviously, he imitated mystical asceticism from the teachings of Gregory Palamas (Bondarchuk, 2012: 74). In his treatise "The Spectacle of Mind", he develops the idea that working in peace makes prayerful self-absorption and mystical knowledge of God impossible: "Before enlightenment, according to Dionysius the Areopagite and after the ecclesiastical, spiritual, moving trail, the first stage is purification, and after purification, they enter into enlightenment, from enlightenment into completion and the ultimate supreme blessing; and the beginning of purification is monasticism, renunciation of the world, flight from the world and weaning from people: a mountain, a cave, a feat of fasting to get rid of an old man and incarnate in a new (after healing passions) man which is Christ" (Vyshensky, 1986: 135).

Vyshensky's life on the holy Mount Athos fully corresponded to his views. In particular, the monk Leontiy in a letter to the Lviv burgher Mykola Zolotorutsky, written on September 9, 1633, called Ivan Vyshensky "a great elder of blessed memory" (Nazaruk, 1997: 136.).

Gerasim Smotrytsky (died in 1594), praising a strong, active, creative personality, subordinates it to the idea of "common good"; glorifying educational and cultural activities, gives priority not to "external knowledge" (secular sciences), but to "internal", divinely inspired wisdom; revealing the inner essence of man and focusing on its spiritual content (Stratiy, 2002: 181-182).

Yov Knyagynytsky (1550-1621) lived and worked within the framework of ascetic-contemplative philosophical views. Educated on 
the Byzantine, ancient Rus, and hesychastic traditions, later consolidated on Mount Athos, he, like I. Vyshensky, saw the main way of spiritual improvement in the departure from earthly life. He considered monastic asceticism to be a form of spiritual protest against reality and a way of salvation (Kashuba, Knyagynytsky, 2005: 365).

A follower of Ivan Vyshensky, Yov Pochaivsky (1550-1651), was the abbot of the Pochaiv monastery. He is credited with the authorship of the collection "Bee of Pochaiv", which glorifies poverty, and monastic life is presented as ideal for the salvation of man, as the highest moral value (Kashuba, Pochaivsky, 2005: 530).

Isaiah Kopynsky (died 1640) had the idea of knowing God through the knowledge of the created world. It was transformed by the Hesychasts into mystical knowledge of God, that is, ascetic selfknowledge and self-immersion. Kopynsky is guided by all the principles of hesychastic spiritual activity, instructing his reader in them: "Seek that which is good day and night, and shall not find Him. Seek Him in all the world, in all the ends of the earth, seek Him in glory, in riches, in carnal beauty, in the earthly pleasures; seek Him in all creation, but you will not find Him anywhere. For He is in you, and you do not know Him; you have Him all, but you do not see Him; the kingdom of God is within you, but you seek it elsewhere; inside you is the greatest pleasure, you do not even suspect it" (Kopynsky, 1993: 70). This is, first of all, purification from passions, enlightenment of the mind, self-immersion as a way to self-knowledge, and comprehension of the Divine (Shadyuk, 2015: 24).

Thus, the purpose of man in earthly life, these philosophers saw in the constant self-improvement of the spirit. The highest good of man, which is the knowledge of absolute truth (God), is achieved only through pure contemplation.

\section{CONCLUSIONS}

Based on the above, we note that the ascetic ideal was of great importance in the history of Ukrainian philosophical culture. The Ukrainian ascetic paradigm has gone from the moral-practical, extroverted asceticism of Kievan Rus to the contemplative introverted asceticism of the Ukrainian Baroque. According to the teachings of the holy fathers and the hesychastic teachings, the essential union with God (deification) in the process of His knowledge is achieved through a mystical-ascetic way, which is connected with the struggle against passions.

In our opinion, self-knowledge, self-improvement, moral improvement, self-realization, as deep-essential values and drivers of the 
spiritual formation of Ukrainians, are also ascetic values. Therefore, scientific research in the direction of revealing ways of self-realization will always be relevant for historical and philosophical research.

\section{SUMMARY}

In the article the author tries to analyze the role of asceticism in the spiritual formation of the individual in the context of the Christian tradition of the Ukrainian Middle Ages. The vision of the path of spiritual growth in the philosophical and religious views of the representatives of the Ukrainian Middle Ages in the framework of Christian teaching and ascetic practice is studied. It is noted that the essential merging with God is carried out in a mystical and ascetic way, which involves complex work in the fight against passions. The author considers the role of asceticism in the self-development of the individual, which occurs through religious-spiritual pursuits. According to the Christian ascetic ideal, man is spiritually and physically whole. Asceticism can be considered a principle of selfdevelopment of the individual to meet an important human existential need - self-realization. He is the key to its success. In Rus, the Byzantine ascetic tradition was combined with active love. The asceticism of the Renaissance humanism period is characterized by contemplation and introversion.

Analyzing the views of the Ukrainian Middle Ages on the ascetic path of spiritual formation, the author concludes that they were characterized by the vision of asceticism as a person's approach to God through selfknowledge and moral improvement. The relevance of research on this method of self-development in today's conditions is noted.

\section{REFERENCES}

1. Abramovych D. (1991). Kyievo-Pecherskyi pateryk [KievPechersk Paterik]. Kyiv: Chas. 280 s. [in Ukrainian]

2. Adamchuk M. (2003). Kyivska Rus mizh Skhodom i Zakhodom v X-XII st. Istoriia relihii v Ukraini [Kievan Rus between East and West in the X-XII centuries]. Pratsi XIII Mizhn. nauk. konf. Kn. 1. Lviv: Lohos. S. 70-76. [in Ukrainian]

3. Bondarchuk Ya. (2012). Dukhovnyi podvyh «blazhennoi pamiati velykoho startsia» Ivana Vyshenskoho [The spiritual feat of the "blessed memory of the great elder" Ivan Vyshensky]. Naukovi zapysky. Seriia "Istorychne relihiieznavstvo". Ostroh: Vyd-vo Natsionalnoho universytetu "Ostrozka akademiia". Vypusk 6. S. 64-75. [in Ukrainian] 
4. Vyshenskyi I. (1986). Tvory. [Works]. Kyiv: Dnipro. 247 s. [in Ukrainian]

5. Honcharov H. (2012). Askeza yak dukhovno-somatychna praktyka liudyny [Asceticism as a spiritual and somatic practice of man]. Avtoref. dys. kand. filos. nauk: 09.00.04. Kharkiv: Kharkivskyi natsionalnyi un-t imeni V. Karazina. $23 \mathrm{~s}$. [in Ukrainian]

6. Horskyi V. (1994). Sviati Kyivskoi Rusi [Saints of Kievan Rus]. Kyiv: Abrys. 176 s. [in Ukrainian]

7. Humeniuk S. (2013). Mistychna praktyka isykhii v Ukraini na zlami XVI - XVII st. [The mystical practice of hesychia in Ukraine at the turn of the XVI-XVII centuries]. Humanitarnyi visnyk ZDIA. Zaporizhzhia. № 53. S.156-167. Mystic hesychia practice in Ukraine at the turn of XVI - XVII century. [in Ukrainian]

8. Danyliuk O. (2013). Filosofsko-bohoslovska problema bezmovnosti (movchannia) $\mathrm{v}$ asketychnii tradytsii latynskoho chernetstva [The philosophical and theological problem of silence in the ascetic tradition of Latin]. Relihiia ta sotsium. Chernivtsi: Chernivetskyi nats. un-t № 1. S. 139-143. [in Ukrainian]

9.Zhadan V. (2006). Hedonizm ta asketyzm u dynamitsi kultury [Hedonism and asceticism in the dynamics of culture]. Avtoref. dys. kand. filos. nauk: 17.00.01. Kharkiv: Khark. derzh. akad. kultury. 20 s. [in Ukrainian]

10. Zhadan V. (2005). Universalnye priznaki gedonizma i asketizma [Universal signs of hedonism and asceticism]. Visn. Khark. nats. un-tu im. V. Karazina: Ser. Teoriia kultury i filosofiia nauky. Kharkiv. № 708. S. 56-62. [in Russian]

11. Kashuba M. (2005). Iov Pochaivskyi [Iov Pochaivsky]. Entsyklopediia istorii Ukrainy: T. 3. Kyiv: Nauk. dumka. S. 530. [in Ukrainian]

12. Kashuba M. (2005). Kniahynytskyi Ivan [Knyagynytsky Ivan]. Entsyklopediia istorii Ukrainy: T.4. Kyiv: Nauk. dumka. S. 365. [in Ukrainian]

13. Kopynskyi I. (1993). Alfavit dukhovnyi [Alphabet spiritual]. Istoriia filosofii Ukrainy. Khrestomatiia. Upor. M. Tarasenko, M. Rusyn, A. Bychko ta in. Kyiv: Lybid. S. 72-74. [in Ukrainian]

14. Mozghovyi L. (2011). Isykhastski motyvy $\mathrm{v}$ ukrainskii filosofskii dumtsi XVI-XVII st. [Hesychasm's motifs in Ukrainian philosophical thought XVI-XVII centuries]. Noosfera i tsyvilizatsiia. Donetsk: DVNZ «DonNTU». Vyp.10-11 (12). S.45-49. [in Ukrainian]

15. Nazaruk M. (1997). Ivan Vyshenskyi. Istoriia Ukrainy v osobakh: Lytovsko-polska doba [Ivan Vyshensky. History of Ukraine in persons: Lithuanian-Polish era]. Kyiv: Ukraina. C. 135-142. [in Ukrainian] 
16. Piletskyi Ye. (2012). Pravoslavna askeza: ukrainska tradytsiia [Orthodox austerity: Ukrainian tradition]. Visnyk Kyivskoho natsionalnoho universytetu imeni Tarasa Shevchenka. Kyiv. Seriia: Filosofiia, Politolohiia. Vyp. 106. S. 23-26. [in Ukrainian]

17. Rozumna O. (2004). Asketychnyi ideal v ukrainskii pravoslavnii propovidi simnadtsiatoho stolittia: relihiieznavchofilosofskyi analiz [The ascetic ideal in the Ukrainian Orthodox sermons of the seventeenth century: religious-philosophical analysis]. Avtoref. dys. kand. filos. nauk: 09.00.11. Kyiv: In-t filosofii im. H.S.Skovorody AN Ukrainy. 14 s. [in Ukrainian]

18. Sidak L. (2003). Pryroda i sutnist asketyzmu [The nature and essence of asceticism]. Visnyk Natsionalnoho tekhnichnoho universytetu «KhPI». Zbirnyk naukovykh prats. Filosofiia. Kharkiv: NTU «KhPI». № 2. S. 154-160. [in Ukrainian]

19. Sidak L. (2003). Asketyzm yak pryntsyp samorozvytku ta samorealizatsii oso-bystosti [Asceticism as the principle of selfdevelopment and personal fulfillment]. Avtoref. dys. kand. filos. nauk: 09.00.03. Kharkiv: Khark. viisk. un-t. 16 s. [in Ukrainian]

20. Stratii Ya. (2002). Filosofska dumka v Ukraini [Philosophical thought in Ukraine]. Kyiv: Pulsary. 244 s. [in Ukrainian]

21. Fedotov G. (1990). Svyatye Drevnej Rusi [Saints of Ancient Rus]. Moscow: Moskovskij rabochij. 269 s. [in Russian]

22. Fedotov H. (2001). Khrystyianstvo Kyivskoi Rusi [Christianity of Kievan Rus]. Liudyna i svit. № 8. S. 2-10. [in Ukrainian]

23. Shadiuk T. (2015). Strazhdennist yak dominanta dukhovnoi diialnosti $\mathrm{v}$ ukrainskii relihiino-filosofskii dumtsi XVI - XVII stolit [Suffering as the dominant spiritual activities in the Ukrainian religious and philosophical thought in XVI - XVII centuries]. Visnyk Zhytomyrskoho derzhavnoho universytetu. Zhytomyr. Filosofski nauky. Vyp. 80. S.20-25. [in Ukrainian]

Information about the author: Hudzenko O.,

Candidate of Philosophical Sciences, Associate Professor, Associate Professor at the Department of World History and Philosophy, Lesya Ukrainka Volyn National University 13 Voli ave., Lutsk, Volyn region, 43025, Ukraine 